\title{
A rare thyroid disorder mimicking mitochondrial disease
}

\author{
Adrijan Sarajlija ${ }^{1,2}$, \\ Sladjana Todorovićc ${ }^{3}$, \\ Biljana Alimpić', \\ Maja Čehić'
}

${ }^{1}$ Mother and Child Health Care Institute of Serbia "Dr Vukan Cupic", Pediatric Day Care Hospital, Belgrade, Serbia

2University of Belgrade, School of Medicine, Belgrade, Serbia

${ }^{3}$ Mother and Child Health

Care Institute of Serbia "Dr Vukan Cupic", Department of Endocrinology, Belgrade, Serbia

Primljen - Received: 03/03/2021

Prihvaćen - Accepted: 07/06/2021

\section{Corresponding author:}

Adrijan Sarajlija, MBI, MD, PhD Radoja Dakica 6-8, 11070 Novi Beograd, Serbia adrijans2004@yahoo.com

Copyright: @2021 Adrijan Sarajlija et all. This is an Open Access article distributed under the terms of the Creative Commons Attribution 4.0 International (CC BY 4.0) license.

\section{Summary}

Introduction. Patients affected with Allan-Herndon-Dudley syndrome (AHDS) have a deficiency of monocarboxylate transporter 8 (MCT8), a protein primarily responsible for the transport of triiodothyronine (T3) into the brain. This X-linked disorder affects almost exclusively males with clinical presentation encompassing developmental delay, axial hypotonia, dystonia, poor head control, quadriplegia and absence of speech.

Case reports. Patient 1 is a male child referred to a hospital investigation at 11 months due to severe developmental delay and elevated blood ammonia level $(163 \mathrm{mcmol} / \mathrm{L})$. Hypotonia and dystonic movements were noted at admission, with facial dysmorphic features. Laboratory findings revealed increased blood lactate $(17.2 \mathrm{mmol} / \mathrm{L})$, alanine (533 mcmol/L) and ammonia (391 mcmol/L) concentrations. Serum creatine-kinase levels showed substantial increase over the course of hospitalization up to $6,855 \mathrm{IU} / \mathrm{L}$. Clinical exome sequencing detected a novel hemizygous frameshift insertion c.1456insC in gene SLC16A2, predicted to cause loss of normal protein function either through protein truncation or nonsense-mediated mRNA decay. Segregation genetic testing of the family members revealed that mother, maternal uncle and maternal grandmother carry the same mutation in SLC16A2. The boy's mother experienced learning difficulties through childhood while maternal uncle is severely affected by AHDS. Patient 2 is a boy referred to clinical geneticist due to severe psychomotor delay of unknown etiology. Moderate serum lactate elevation was the only laboratory abnormality during initial investigations. Diagnosis of AHDS was established by clinical exome sequencing, and subsequent hormonal evaluation revealed increased triiodothyronine (T3) level which corresponds well to genetic diagnosis.

Conclusion. Presence of lactic acidosis and/or hyperammonemia in children with severe developmental delay is not specific for inborn disorders of energy production, such as mitochondrial disease. Clinicians should consider thyroid hormones profiling in cases of unexplained severe developmental delay in male children, especially if associated with axial hypotonia and dystonic movements.

Key words: Allan-Herndon-Dudley syndrome, hyperammonemia, lactic acidosis 


\section{Introduction}

Seventy years after the first clinical description of Allan-Herndon-Dudley syndrome (AHDS), it was found that mutations in SLC16A2 are the genetic basis of this rare disease [1]. Patients affected with AHDS have a deficiency of monocarboxylate transporter 8 (MCT8), a protein primarily responsible for the transport of triiodothyronine (T3) into the brain. This X-linked disorder affects almost exclusively males and its incidence could be underestimated due to absence of pathognomonic clinical features. With the onset of genome-based diagnostic approach, substantial number of new cases has been reported in recent years, from different ethnic and geographic backgrounds [2-4]. Clinical presentation of AHDS is variable but in most cases encompasses severe developmental delay, axial hypotonia, dystonia, poor head control, quadriplegia and absence of speech $[5,6]$. Brain MRI findings usually reveal delayed myelination [7]. Recently, treatment options for AHDS have emerged with the use of T3 analogues such as tiratricol (Triac) [8].

Pattern of hormonal status in affected children includes elevated 3,3',5-triiodothyronine (T3), high or normal thyroid-stimulating hormone (TSH) and low or normal tetraiodothyronine (T4) (5). However, there have been reports of AHDS patients with normal thyroid status [9] or with unusual laboratory findings, e.g. elevated serum lactate and/or ammonia $[9,10]$.

Small number of female carriers of mutations in MCT8 have presented with manifestations related to the AHDS [10]. Clinical spectrum in female carriers ranges from asymptomatic to mild mental retardation, and in some cases to more complete clinical and hormonal profile of AHDS [11]. Herein, we describe two boys with distinct presentation of AHDS.

\section{Case reports}

Patient 1 is a male child born at term from the first uneventful pregnancy of non-consanguineous parents with birth weight of 3,500 grams, birth length of $51 \mathrm{~cm}$ and normal head circumference $(35 \mathrm{~cm})$. Apgar score was 10 at first minute. Hypotonia was already noted in neonatal period, but the boy was not referred to hospital investigations until 11 months. The reasons for referral were a severe developmental delay and elevated blood ammonia level $(163 \mathrm{mcmol} / \mathrm{L})$ registered during an outpatient neurological evaluation. Hypotonia and dystonic movements were noted at admission. Face was noted as wide, with epicanthal folds and micrognathia and normal head circumference (P25-50). Bilateral cryptorchidism was verified. Laboratory findings revealed high blood lactate $(17.2 \mathrm{mmol} / \mathrm{L})$ and ammonia (391 mcmol/L) concentrations. Arterial blood $\mathrm{pH}$ was 7.22 , with base excess at $-12.4 \mathrm{mmol} / \mathrm{L}$. Level of creatine-kinase in serum showed substantial increase over the early course of hospitalization, from $819 \mathrm{IU} / \mathrm{L}$ at admission to $6855 \mathrm{IU} / \mathrm{L}$ on the second day. Amino acid analysis in plasma revealed increase of alanine $(533 \mathrm{mcmol} / \mathrm{L})$ while urine organic acid profile as well as plasma total carnitine, free carnitine and acylcarnitine profile were normal. MRI of the brain showed delayed myelination with thin corpus callosum and overall reduction of supratentorial white matter. Acidosis was corrected and thiamine and carnitine were introduced in maintenance dosage, due to suspicion of inborn error of energy metabolism. Overall condition of the child remained stable despite laboratory abnormalities, and he was discharged after 20 days. Ammonia level was reduced to 64 mc$\mathrm{mol} / \mathrm{L}$ at discharge. Clinical exome sequencing was performed at 21 months and detected a novel hemizygous frameshift insertion c.1456insC in gene SLC16A2. The mutation was predicted to cause loss of normal protein function either through protein truncation or 
nonsense-mediated mRNA decay. After acquiring genetic diagnosis, thyroid hormone profile was performed for the first time and revealed elevated T3 and free T3 plasma levels, high TSH and low free T4 concentration: TSH $9.71 \mathrm{mIU} / \mathrm{L}$ (ref. 0.27-4.2), fT4 6.87 pmol/L (ref. 12.0-22.0), fT3 15.74 pmol/L (ref. 2.92-7.53), T3 5.68 pmol/L (ref. 0.6-3.9)

Segregation genetic testing of the family members revealed that mother, maternal uncle and maternal grandmother carry the same mutation in SLC16A2. The boy's mother had learning difficulties through childhood and adolescence. Maternal uncle is affected with severe mental retardation and quadriplegia. Maternal grandmother does not have any clinical manifestations relevant to AHDS. $X$-inactivation study was performed in female carriers in this family and it revealed similar pattern of skewed inactivation of $\mathrm{X}$ chromosome in both, favouring chromosome without SLC16A2 mutations (90:10).

During the second year of life, severe developmental delay, absence of head control and dystonic movements were persevering. Blood ammonia level was measured at follow up visits every three months, and it showed non-consistent findings, ranging from $49 \mathrm{mc}-$ $\mathrm{mol} / \mathrm{L}$ to $377 \mathrm{mcmol} / \mathrm{L}$, without signs of acute encephalopathy. At two years of age, treatment with L-thyroxine was introduced due to consistently elevated TSH level, but without apparent clinical effect.

Patient 2 is a boy referred to clinical geneticist due to severe psychomotor delay of unknown etiology at 18 months. Clinical exam revealed abundance of involuntary dystonic movements. Moderate serum lactate elevation $(5.1 \mathrm{mmol} / \mathrm{L})$ was the only laboratory abnormality during initial investigations. Diagnosis of AHDS was established by clinical exome sequencing when novel variant c.45G $>A$ in SLC16A2 gene was found. Subsequent hormonal evaluation revealed increased $\mathrm{T} 3$ level and normal TSH which corresponds well to the established genetic diagnosis. Delay of psychomotor development is severe with inability to speak or sit independently at the age of 2.5, while serum lactate remains mildly to moderately elevated during follow-up. At this age, delayed myelination was the most prominent finding of the performed brain MRI. Triac was recently initiated at the age of 3 and discrete motor improvement was observed over the weeks of therapy.

\section{Discussion}

Severe developmental delay in a hypotonic child with elevated blood lactate and/or ammonia, as observed in our patients, was highly suggestive of mitochondrial disease. Only after the exome sequencing, the correct diagnosis of AHDS was established. Hyperlactatemia and hyperammonemia have already been anecdotally reported in patients with AHDS $[10,11]$. Herzovich et al. attributed these findings to peripheral hyperthyreotic effects, speculating that high catabolic rate in skeletal muscles of AHDS patient results in such abnormalities: high lactic acid was explained by the enhanced glycolysis/glycogenolysis, and high ammonia in plasma by accelerated purine nucleotide catabolism [12]. Significant hyperlactatemia was also noted in case report by Langley et al., but ammonia level was normal in this AHDS patient [10]. Elevated serum concentration of $C K$ was verified in patient 1 as unique finding for AHDS so far. However, several authors reported hyperammonemia and elevated serum hyperCKemia in patients with hypothyroidism [13]. In a study by Turkish authors, CK levels have been shown to negatively correlate with TSH levels in both overt and subclinical hypothyroidism [14]. Therefore, the transitory presence of hyperCKemia in our patient 1 could not be explained by thyroid disorder.

The impact of thyroid hormones on mitochondrial metabolism has been extensively studied [15]. The role of T3 as the inducer 
of mitochondrial biogenesis and regulator of mitochondrial gene expression is recognized [16]. In recent paper, Zimmerman et al. reported a significant reduction of respiratory chain complex I in oncocytic cells of patients with hypothyroidism [17]. These authors propose possible role of complex I deficiency in immune pathogenesis of hypothyroidism. Reduced presence of respiratory chain complex I in muscle cells of AHDS patient in our report, casts a new light onto the relationship of thyroid disorders and mitochondrial metabolism. There are, however, scarce reports of mitochondrial disturbance in the presence of thyrotoxicosis, such as massive enlargement of these organelles and activation of mitochondrial apoptotic pathway [18]. These processes could underlie some of the observed similarities between AHDS and mitochondriopathies.

There are reports of AHDS patients previously considered to have other genetic diseases. Vaurs-Barrière et al. showed that a significant portion of patients with initial diagnosis of Pelizaeus-Merzbacher were found to actually suffer of AHDS. A number of AHDS cases was genetically diagnosed with the use of next generation sequencing tools $[3,19]$. Methodology of NGS proves valuable in population of patients with severe developmental delay of unclear etiology. However, use of much cheaper and quicker thyroid hormone profiling could direct the genetic analysis toward a single gene analysis for the confirmation of AHDS.

Funding source. The authors received no specific funding for this work.

Ethical approval. This article does not contain any studies with human participants performed by any of the authors.
Neuroimaging is one of the key diagnostic tools when dealing with children with profound developmental delay associated with movement disorder, as seen in AHDS. Inadequate myelination and brain atrophy have been recognized as the imaging features of this particular disorder, but they are not universally present [6]. In a proportion of patients central white matter myelination shows gradual improvement over time [20,21]. Studies have revealed that MCT8 deficiency, diminished thyroid stimulation of oligodendrocytes leading to hypomyelination in critically important period of early life [22]. Drawing from our own experience with two patients, brain MRI can be a helpful tool in establishing suspicion of AHDS. Also, follow-up of the myelination status can be important part of treatment response assessment.

\section{Conclusion}

Presence of lactic acidosis and/or hyperammonemia in male children with severe developmental delay is not specific for inborn disorders of energy production, such as mitochondrial disease. Clinicians should consider thyroid hormones profile in cases of unexplained severe developmental delay in male children, especially if associated with axial hypotonia, dystonic movements and MRI findings of hypomyelination, even in presence of atypical laboratory findings.

Conflict of interest. The authors declare no conflict of interest.

Acknowledgment for providing service of clinical exome sequencing: Lluís Armengol Dulcet, PhD, Quantitative Genomic Medicine Laboratories, S.L., Barcelona, Spain and Aleš Maver, MD, PhD, University Medical Center, Center for Mendelian Genomics, Ljubljana Slovenija. 
References:

1. Dumitrescu AM, Liao XH, Best TB, Brockmann K, Refetoff S. A novel syndrome combining thyroid and neurological abnormalities is associated with mutations in a monocarboxylate transporter gene. Am J Hum Genet 2004;74(1):168-75.

2. Shimojima K, Maruyama K, Kikuchi M, Imai A, Inoue K, Yamamoto T. Novel SLC16A2 mutations in patients with Allan-Herndon-Dudley syndrome. Intractable Rare Dis Res 2016;5(3):214-7.

3. Armour CM, Kersseboom S, Yoon G, Visser TJ. Further Insights into the Allan-Herndon-Dudley Syndrome: Clinical and Functional Characterization of a Novel MCT8 Mutation. PloS One 2015;10(10):e0139343.

4. Kim JH, Kim YM, Yum MS, Choi JH, Lee $\mathrm{BH}$, Kim GH, Yoo HW. Clinical and endocrine features of two Allan-Herndon-Dudley syndrome patients with monocarboxylate transporter 8 mutations. Horm Res Paediatr 2015;83(4):288-92.

5. Groeneweg S, Visser WE, Visser TJ. Disorder of thyroid hormone transport into the tissues. Best Pract Res Clin Endocrinol Metab 2017;31(2):241-53.

6. Remerand G, Boespflug-Tanguy $\mathrm{O}$, Tonduti D, Touraine R, Rodriguez D, Curie A, et al; RMLX/ AHDS Study Group. Expanding the phenotypic spectrum of Allan-Herndon-Dudley syndrome in patients with SLC16A2 mutations. Dev Med Child Neurol 2019;61(12):1439-47.

7. Tonduti D, Vanderver A, Berardinelli A, Schmidt JL, Collins CD, Novara F, Genni AD, Mita A, Triulzi F, Brunstrom-Hernandez JE, Zuffardi O, Balottin U, Orcesi S: MCT8 deficiency: extrapyramidal symptoms and delayed myelination as prominent features. J Child Neurol 2013;28(6):795-800.

8. Bauer AJ. Triac in the treatment of Allan-Herndon-Dudley syndrome. Lancet Diabetes Endocrinol 2019;7(9):661-3.

9. Boccone L, Dessì V, Meloni A, Loudianos G. Allan-Herndon-Dudley syndrome (AHDS) in two consecutive generations caused by a missense MCT8 gene mutation. Phenotypic variability with the presence of normal serum T3 levels. Eur J Med Genet 2013;56(4):207-10.
10. Langley KG, Trau S, Bean LJ, Narravula A, Schrier Vergano SA. A 7-month-old male with Allan-Herndon-Dudley syndrome and the power of T3. Am J Med Genet A 2015;167A(5):1117-20.

11. Herzovich V, Vaiani E, Marino R, et al. Unexpected Peripheral Markers of Thyroid Function in a Patient with a Novel Mutation of the MCT8 Thyroid Hormone Transporter Gene. Horm Res 2006;67(1):1-6.

12. Frints SG, Lenzner $S$, Bauters $M$, Jensen LR, Van Esch H, des Portes V, et al. MCT8 mutation analysis and identification of the first female with Allan-Herndon-Dudley syndrome due to loss of MCT8 expression. Eur J Hum Genet 2008;16(9):1029-37.

13. De Nardo, Franconi G, Sabino D. Hyperammonemia during hypothyroidism: an unusual biohumoral finding normalized by hormonal replacement treatment. Ann Ital Med Int 1999;14(3):196-201.

14. Hekimsoy Z, Oktem IK. Serum creatine kinase levels in overt and subclinical hypothyroidism. Endocr Res 2005;31(3):171-5.

15. Lanni A, Moreno M, Goglia F. Mitochondrial Actions of Thyroid Hormone. Compr Physiol 2016;6(4):1591-607.

16. Weitzel JM, Iwen KA, Seitz HJ. Regulation of mitochondrial biogenesis by thyroid hormone. Exp Physiol 2003;88(1):121-8.

17. Zimmermann FA, Neureiter D, Feichtinger RG, Trost A, Sperl W, Kofler B, Mayr JA. Deficiency of Respiratory Chain Complex I in Hashimotor Thyroiditis. Mitochondrion 2016;26:1-6.

18. Upadhyay G, Singh R, Kumar A, Kumar S, Kapoor A, Godbole MM. Severe hyperthyroidism induces mitochondria-mediated apoptosis in rat liver. Hepatology 2004;39(4):1120-30.

19. Tsurusaki Y, Osaka H, Hamanoue H, Shimbo H, Tsuji M, Doi H, Saitsu H, Matsumoto N, Miyake N. Rapid detection of a mutation causing X-linked leucoencephalopathy by exome sequencing. J Med Genet 2011;48(9):606-9.

20. Azzolini S, Nosadini M, Balzarin M, Sartori $S$, Suppiej A, Mardari R, et al. Delayed myelination is not a constant feature of AllanHerndon-Dudley syndrome: report of a new 
case and review of the literature. Brain Dev 2014;36(8):716-20.

21. Vancamp P, Demeneix BA, Remaud S. Monocarboxylate Transporter 8 Deficiency: Delayed or Permanent Hypomyelination?. Front Endocrinol (Lausanne) 2020;11:283.
22. Kim MJ, Petratos S. Oligodendroglial Lineage Cells in Thyroid Hormone-Deprived Conditions. Stem Cells Int 2019;2019:5496891.

\title{
Redak poremećaj tireoidne funkcije sa ispoljavanjem sličnim mitohondropatiji
}

\author{
Adrijan Sarajlija ${ }^{1,2}$, Slađana Todorović ${ }^{3}$, Biljana Alimpić ${ }^{\text {, Maja Čehić }}$ \\ 'Institut za zdravstvenu zaštitu majke i deteta Srbije „Dr Vukan Čupić”, Pedijatrijska dnevna bolnica, \\ Beograd, Srbija \\ ${ }^{2}$ Univerzitet u Beogradu, Medicinski fakultet, Beograd, Srbija \\ ${ }^{3}$ Institut za zdravstvenu zaštitu majke i deteta Srbije „Dr Vukan Čupić", Odeljenje za endokrinologiju, \\ Beograd, Srbija
}

Uvod. Oboleli od Allan-Herndon-Dudleyevog sindroma (AHDS) imaju nedostatak monokarboksilatnog transportnog proteina 8 (MCT8) koji omogućava ulazak trijodtironina (T3) u centralni nervni sistem. Ovaj X-vezani poremećaj uslovljen mutacijama u SLC16A2 genu pogađa gotovo isključivo dečake i klinički se ispoljava usporenim psihomotornim razvojem, hipotonijom osovine tela, distonijom, kvadriplegijom i odsustvom razvoja govora.

Prikaz slučajeva. Pacijent 1 je muško dete upućeno na ispitivanje u uzrastu od 11 meseci zbog usporenog psihomotornog razvoja i povišene koncentracije amonijaka u krvi ( $163 \mathrm{mcmol} / \mathrm{L})$. Na prijemu se uočavaju hipotonija, distonični pokreti i diskretna dismorfija lica. U laboratorijskim nalazima iz krvi dobijaju se povišene koncentracije laktata $(17,2 \mathrm{mmol} / \mathrm{L})$, alanina $(533 \mathrm{mcmol} / \mathrm{L})$, amonijaka (391 mcmol/L) i serumske kreatin-kinaze (postepeni porast do 6855 IU/L). Kliničko egzomsko sekvencioniranje pokazalo je postojanje nove hemizigotne frameshift insercije c.1456insC u genu SLC16A2. Segregaciona analiza sprovedena kod članova porodice je pokazala da majka, ujak i baba po majci nose istu mutaciju u SLC16A2. Dečakova majka je imala određenih poteškoća u učenju tokom detinjstva, dok ujak ima kliničku sliku AHDS. Pacijent 2 je dečak upućen kliničkom genetičaru zbog teškog psihomotornog zastoja. $U$ inicijalnim analizama se registruje umereno povišena koncetracija laktata u krvi. Dijagnoza AHDS je postavljena na osnovu kliničkog sekvencioniranja egzoma, a dalja dijagnostička obrada je pokazala povišene vrednosti T3 u krvi što odgovara ovoj dijagnozi.

Zaključak. Prisustvo laktične acidoze i/ili hiperamonijemije kod dece sa teškim psihomotornim zaostajanjem ne susreće se samo kod urođenih poremećaja energetskog metabolizma, odnosno mitohondropatija. Ispitivanje statusa tireoidnih hormona u slučaju psihomotornog zastoja nepoznate etiologije kod dece muškog pola ima značaja, pogotovo ako su prisutni aksijalna hipotonija i distonični pokreti.

Ključne reči: Allan-Herndon-Dudley sindrom (AHDS), hiperamonijemija, laktična acidoza 
